\title{
Reserach автісів: Effect of phosphorus fertilizers on oil seed crops
}

\section{SWETHA KUMARI AND J.D. SARITHA}

Article Chronicle:

Received :

10.07.2017;

Accepted :

25.07.2017

KEY WoRds :

Phosphorus,

Fertilizers, Seed crpps
SUMMARY : Phosphorus is an important primary nutrient and enhances root growth there by facilitating absorption of water and nutrients from deeper layers. Phosphorus stimulates not only root growth but also hastens the maturity of oilseed crops. This nutrient required for synthesis of oils, proteins, nucleic acids and is also involved in the formation of glucosinolates, which on hydrolysis increases the oil content which intern influences the final pod yield and oil yield (Jeetarwal et al., 2015). When applied to the soil, the applied $\mathrm{P}$ get fixed in the form of iron and aluminium phosphates in acid soils and as calcium phosphates in the saline or calcareous soils, there by the efficiency of applied $\mathrm{P}$ seldom to exceed 10-30\% ( Swarup, 2002).

How to cite this article : Kumari, M. Swetha and Saritha, J.D. (2017). Effect of phosphorus fertilizers on oil seed crops. Agric. Update, 12(TECHSEAR-3) : 749-754; DOI: 10.15740/HAS/AU/12.TECHSEAR(3)2017/ 749-754.
Author for correspondence :

M. SWETHA KUMARI Department of Agronomy, College of Agriculture (PJTSAU), HYDERABAD (TELANGANA) INDIA Email : swethassac92@ gmail.com

See end of the article for authors' affiliations 